\title{
The role of microorganisms at different stages of ecosystem development for soil formation
}

\author{
S. Schulz ${ }^{1}$, R. Brankatschk ${ }^{2}$, A. Dümig ${ }^{3}$, I. Kögel-Knabner ${ }^{3,4}$, M. Schloter ${ }^{1}$, and J. Zeyer ${ }^{2}$ \\ ${ }^{1}$ Helmholtz Zentrum München, German Research Center for Environmental Health, Research Unit Environmental Genomics, \\ Ingolstädter Landstr. 1, 85764 Neuherberg, Germany \\ ${ }^{2}$ ETH Zurich, Environmental Microbiology, Institute of Biogeochemistry and Pollutant Dynamics, Universitätsstr. 16,8092 \\ Zurich, Switzerland \\ ${ }^{3}$ Technische Universität München, Lehrstuhl für Bodenkunde, 85350 Freising-Weihenstephan, Germany \\ ${ }^{4}$ Technische Universität München, Institute for Advanced Study, Lichtenbergstrasse 2a, 85748 Garching, Germany
}

Correspondence to: M. Schloter (schloter@helmholtz-muenchen.de)

Received: 27 December 2012 - Published in Biogeosciences Discuss.: 1 February 2013

Revised: 30 April 2013 - Accepted: 8 May 2013 - Published: 18 June 2013

\begin{abstract}
Soil formation is the result of a complex network of biological as well as chemical and physical processes. The role of soil microbes is of high interest, since they are responsible for most biological transformations and drive the development of stable and labile pools of carbon $(\mathrm{C})$, nitrogen $(\mathrm{N})$ and other nutrients, which facilitate the subsequent establishment of plant communities. Forefields of receding glaciers provide unique chronosequences of different soil development stages and are ideal ecosystems to study the interaction of bacteria, fungi and archaea with their abiotic environment. In this review we give insights into the role of microbes for soil development. The results presented are based on studies performed within the Collaborative Research Program DFG SFB/TRR 38 (http://www.tu-cottbus.de/ecosystem) and are supplemented by data from other studies. The review focusses on the microbiology of major steps of soil formation. Special attention is given to the development of nutrient cycles on the formation of biological soil crusts (BSCs) and on the establishment of plant-microbe interactions.
\end{abstract}

\section{Introduction}

Microbial communities can be considered as architects of soils (Rajendhran and Gunasekaran, 2008) and many ecosystem services that are linked to terrestrial ecosystems, including plant production, safeguarding of drinking water or $\mathrm{C}$ sequestration, are closely linked to microbial activities and their functional traits (Torsvik and Øvreås, 2002). Vice versa, the soil matrix as well as chemical and physical properties of soils, like quality and amount of soil organic matter, $\mathrm{pH}$, and redox conditions, have a pronounced influence on the dynamics of the microbial community structure and function in soils (Lombard et al., 2011). This close interplay between abiotic conditions and the soil biosphere is one of the most fascinating issues as far as earth sciences are concerned, with huge implications on environmental as well as human health (van Elsas et al., 2008). Due to the complex interactions, it is not surprising that the formation of soils with a high level of fertility is a result of more than hundreds of years of soil "evolution" (Harrison and Strahm, 2008). As a result of global change in general and the loss of soil quality in particular, many soils are threatened. Thus, there is a huge need to develop strategies for a sustainable protection of soils for future generations. In this respect the knowledge gained from soil chronosequences might help to improve our understanding about the development of biotic-abiotic interplays and to identify factors that drive the formation of soils (Doran, 2002).

Studies on the development of abiotic and biotic interactions are very complex. They require both different spatial and temporal scales (Ollivier et al., 2011). Microbes act on a scale of $\mu \mathrm{m}^{3}$ and form biogeochemical interfaces with the soil matrix, shaping their own environment (Totsche et al., 2010). It remains largely unknown how many interfaces are connected and how many interfaces are needed for the 
stability of soil. Furthermore, microbes can change their phenotype within minutes depending on the present environmental conditions at those interfaces by gene induction or repression (Sharma et al., 2012). The corresponding transcripts often have half times in the range between seconds and minutes. Putting this in the frame of soil formation which may take centuries is a highly challenging issue.

In addition to that, the diversity of soil microbes is huge and can still be considered as a black box (Simon and Daniel, 2011); consequently nobody is so far able to give exact numbers on the species or, even more important, on the ecotype richness in one unit of soil. Microbes are also able to easily exchange genetic information, which induces a very fast and ongoing diversification of organisms in natural environments, and the genetic flexibility of the whole soil microbiome can be considered enormous (Monier et al., 2011). Finally, most functional traits, for example the degradation of plant litter or the development of food web structures and closed nutrient cycles, are not a result of a single organism but of microbial communities which closely interact which each other (Aneja et al., 2006). Even the development of symbiotic interactions between plants and microbes in soil (e.g. mycorrhization of plants or legume-rhizobia interactions) are much more complex than described in text books, including the involvement of a diverse number of "helper organisms" during the infection phase (Frey-Klett et al., 2007). Timescales for community development and stable microbiomes are therefore still a highly challenging topic of research, and in many cases concepts do not even exist for the formation of microbial communities on the basis of single organisms being present at a certain point in time of ecosystem genesis.

Forefields of receding glaciers are ideal field sites to study the initial steps of soil formation, as in a close area of some square kilometres a chronosequence of soils of different development stages can be found. As time is substituted by space, a simultaneous comparison of the formation of organismic interactions and of abiotic-biotic interfaces at different development stages is possible. Since the end of the Little Ice Age around $150 \mathrm{yr}$ ago, most alpine glaciers have been receding at an increasing rate (Paul et al., 2004). A recent survey on 97 Swiss glaciers revealed that today most glaciers show an annual recession of dozens of metres (Paul et al., 2007). A similar trend can be observed in alpine zones dominated by permafrost. Permanent permafrost is more and more occurring in deeper soil horizons (Paul et al., 2007).

Detailed studies on glacier recession and soil formation have been performed at the Damma Glacier in Central Switzerland (Kobierska et al., 2011). The length of this glacier has been monitored since 1921, and the rate of recession is currently about $10 \mathrm{~m}$ per year (http://glaciology. ethz.ch/swiss-glaciers/). The forefield has a north-eastern exposition, an inclination of about $21 \%$, and is located at $2050 \mathrm{~m}$ a.s.1. (http://map.geo.admin.ch/). As depicted in Fig. 1, the glacier forefield is flanked by two lateral moraines,

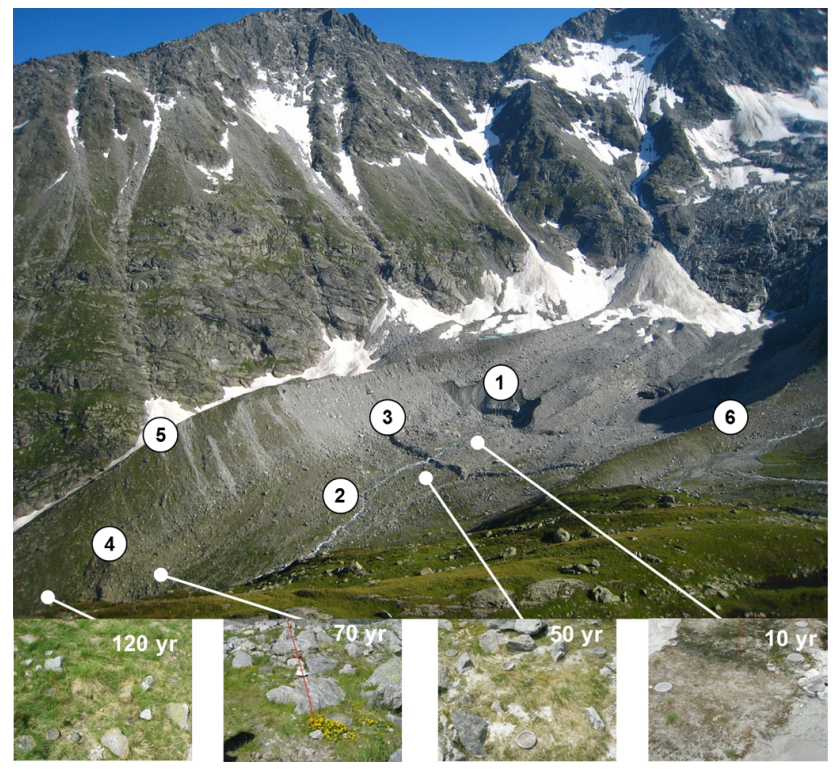

Fig. 1. The forefield of the Damma Glacier (Switzerland) as it developed in response to the continuous retreat of the glacier. The numbers mark important corner points of the forefield: (1) the glacier terminus, (2) the glacier stream, (3) moraine from 1992, (4) moraine from 1928, (5) the south flanking moraine and (6) the north flanking moraine, which both date back to the end of the Little Ice Age in 1850. The small pictures are closeups from 10, 50, 70 and $120 \mathrm{yr}$ ice-free soils, where the $10 \mathrm{yr}$ site is situated in the initial part of the glacier forefield (6-13 yr), 50 and $70 \mathrm{yr}$ sites in the intermediately developed sites (50-80 yr) and the $120 \mathrm{yr}$ site in the most developed part of the forefield (110-160 yr). Photos: A. Zumsteg.

which emerged during the Little Ice Age around 1850. Two brief advancements of the glacier in 1928 and 1992 resulted in two further moraines, which divided the forefield in three parts: initial $(6-13 \mathrm{yr})$, intermediate $(50-80 \mathrm{yr})$ and developed sites (110-150 yr).

In this review we summarized our knowledge about the role of microorganisms in soil development by using current data from the chronosequence of the forefield of the Damma Glacier and how this improves our view of soils as the most important bioreactor on earth.

\section{Setting the stage for microbial activity: the role of weathering}

The formation of fertile soils from inorganic bedrock implies a complex interaction of physical, chemical and biological processes. The rate of the soil development is dominated by variables such as climate, bedrock type, topography, time, microorganisms and plants (Paul and Clark, 1996; Egli et al., 2011). Usually hundreds of years are required to convert inorganic precursors to humus and eventually distinct soil horizons. 
The climate in alpine zones is characterized by high precipitation and pronounced fluctuations of temperatures. For example, in the cities of Basel, Bern and Zurich (Switzerland, all at an altitude of $<550 \mathrm{~m}$ a.s.l.) the annual precipitation is in the range of $140-160 \mathrm{~cm} \mathrm{yr}^{-1}$ (http://www.meteosuisse. admin.ch/web/en.html). In contrast, in the Alps, at an altitude of $>2500 \mathrm{~m}$ a.s.l., the precipitation is usually $>250 \mathrm{~cm} \mathrm{yr}^{-1}$. Nevertheless, microbes can be subject to dry stress in parts of the glacier forefield, which are dominated by rocks and sand with a low water holding capacity. In addition, solar radiation (UV and visible range) increases with altitude due to decreasing optical air masses (Blumenthaler et al., 1997). For UVB, the increase is about $9 \%$ per $1000 \mathrm{~m}$ and in highaltitude glacier forefields; severe effects of UVB on microorganisms cannot be excluded. UVB damage results from a direct absorption of radiation by target molecules such as DNA and proteins, and usually microorganisms produce secondary metabolites as a photoprotective mechanism.

In the mountains not only the radiation during daytime but also the back radiation during night-time is higher than in the lowlands. As a consequence, the temperature fluctuations on the rock and soil surfaces are very pronounced and can easily go beyond $40^{\circ} \mathrm{C}$ within 12 hours (unpublished data). It is remarkable that the snow cover in winter and spring provides a good insulation and temperatures on snow covered soils usually do not fall below $0{ }^{\circ} \mathrm{C}$. Exceptions can be time periods in fall when the air temperatures drop significantly below $0{ }^{\circ} \mathrm{C}$ and the snow cover only amounts to a few centimetres (Körner et al., 1999)

The forefield of a receding glacier consists of very heterogeneous and distinct morphotypes such as moraines, rock fields, floodplains, sand hills, erosion channels and mudslides. From a geomorphological point of view, these features are formed by complex interactions of glacial, periglacial, fluvial and gravitational forces. In order to allow a meaningful analysis of experimental data along the chronosequence, these morphotypes have to be considered, and in addition to that geostatistical methods have to be employed. In the past, the mapping of the morphotypes required laboursome field work using triangulation, while today it is usually done by lidar, radar interferometry and photogrammetry (Harris et al., 2009). The weathering of rocks depends on the composition of the bedrock as well as on the environmental conditions. For example, calcareous rocks are mainly subject to chemical weathering (acidic dissolution of the calcium carbonate) whereas siliceous rocks are mainly fractured as a consequence of freezing-thawing cycles. At the Damma Glacier for example, the bedrock consists of Aare granite composed of quartz, plagioclase, potassium feldspar, biotite and muscovite (Kobierska et al., 2011). The mineralogy of the sand, silt and clay fractions in the glacier forefield reflects the composition of the bedrock.

Besides chemical and physical processes at this stage, bacteria and fungi can also contribute substantially to the weathering of mineral surfaces. Several biogeochemical processes have been described which catalyse the decay of minerals and the mobilization of nutrients. The mechanisms include enzymatically catalysed reactions, the local reduction of the $\mathrm{pH}$, and the production of complexing agents such as cyanide, oxalate and gluconic acid and the excretion of transport vehicles such as siderophores (Mavris et al., 2010; Styriakova et al., 2012). However, many reports on the role of bacteria and fungi for weathering mainly cover phenomenological experiments in the laboratory (e.g. using fluorescence staining of biofilms on mineral surfaces or scanning electron microscopy of weathered minerals) and do not necessarily allow the prediction of the rates of biological weathering under field conditions. Direct field observations are rare and include for example a study on the role of microorganisms in phosphorus $(\mathrm{P})$ cycling in the forefield of the Damma Glacier (Tamburini et al., 2010), which revealed a shift from substrate derived $\mathrm{P}$ at initial sites to internal $\mathrm{P}$ turnover at more developed sites.

For the establishment of microbial life in a glacier forefield, both the chemical composition of the bedrock as well as the physical structure of the weathered fractions are important. Siliceous rocks contain a number of minerals which contain essential elements (e.g. apatite is a source of phosphorous) and thus favour microbial life. In contrast, the weathering of calcareous rocks releases very few elements which facilitate the growth of microorganisms. Some rocks such as serpentinites even release toxic elements (e.g. Nickel, Cadmium) which prevent plant life (Bratteler et al., 2006) and which may also inhibit microbial activities.

Soil aggregation is of upmost importance in controlling microbial structures, functions and plant life. Ideally, the weathered fractions in a glacier forefield include sand (fraction $2 \mathrm{~mm}$ to $63 \mu \mathrm{m})$, silt ( 63 to $2 \mu \mathrm{m})$ and clay ( $<2 \mu \mathrm{m})$, and thus allow a good diffusion of gases and bacterial motility as well as high ion exchange and water holding capacities. Particularly clay is often found in glacier forefields (Kobierska et al., 2011; Mavris et al., 2011), and this is essential for aggregate formation and the stabilization of soil organic matter (Paul and Clark, 1996).

In the forefield of the Damma Glacier, there is little change in the phyllosilicate clay mineralogy, whereas the amount of poorly crystalline $\mathrm{Fe}$ oxides and $\mathrm{Al}$ phases increased with soil development, reflecting a growing potential for soil organic C stabilization (Dümig et al., 2011). In contrast to strongly increasing quantities, only small changes in the composition of the $\mathrm{Fe}$ and $\mathrm{Al}$ pools were detected during initial pedogenesis. Fe oxides and inorganic $\mathrm{Al}$ phases mainly remained poorly crystalline.

\section{Development of initial $\mathrm{C}$ and $\mathrm{N}$ cycles}

At the Damma Glacier important macronutrients, such as phosphorus and sulfur (S), are part of the mineral composition. Therefore, microbial activity might accelerate the 
release of those elements from the bedrock to supply living organisms with $\mathrm{P}$ and $\mathrm{S}$. In contrast, $\mathrm{C}$ and $\mathrm{N}$ are not part of the mineral composition and are scarce in the initial soils, stressing the importance of studying these geochemical cycles from the view of microorganisms. The concentrations of the most abundant nutrients are summarized in Table 1.

In the initial soils, total $\mathrm{C}$ content fluctuates around $700 \mu \mathrm{g} \mathrm{C} \mathrm{g}-1$. Microbial C reached up to $50 \mu \mathrm{g} \mathrm{Cg}^{-1}$, which is a value also found in semi-arid grassland soils (Dijkstra et al., 2006), indicating a high turnover rate of $C$ (Table 1). This is in agreement with soil respiration rates, which are in the range of $130 \mu \mathrm{g} \mathrm{Cg} \mathrm{g}^{-1} \mathrm{a}^{-1}$ (Gülland et al., 2013a). The source of organic $\mathrm{C}$ in the initial soils, however, is a matter of controversy. Three different sources potentially contribute $\mathrm{C}$ to the initial soil. First, the deposition of allochthonous organic matter, such as plant litter, insects, and soot particles, contributes considerable amounts of C (Hodkinson et al., 2003). Measurements of allochthonous $\mathrm{C}$ deposition range from $7.5 \mathrm{~kg} \mathrm{Cha}^{-1} \mathrm{a}^{-1}$ at the Damma Glacier (Brankatschk et al., 2011) to $34 \mathrm{~kg} \mathrm{Cha}^{-1} \mathrm{a}^{-1}$ at Toolik Lake, Alaska (Fahnestock et al., 1998). Second, C inputs from close-by cyanobacterial and algal communities, such as cryoconite holes or patches of snow algae, might contribute $\mathrm{C}$ to the forefield (Kaštovská et al., 2007; Sawstrom et al., 2002; Stibal et al., 2008). Third, ancient $C$ might be present in the forefield of the Damma Glacier. During the Holocene, glacier basins were vegetated. Dating the sub-fossil remains of trees and peat, warm periods, e.g. around the years 2000, 3900 and 4900 BP, were identified (Joerin et al., 2006). At this time glacier valleys were covered by peat bogs with birch and willow trees. Similarly, at the Damma Glacier it appears possible that $\mathrm{C}$ originating from ancient vegetation is mixed into the initial soil. This hypothesis is supported by ${ }^{14} \mathrm{C}$ measurements on the carbon dioxide released from the initial soils by respiration. The $\delta^{14} \mathrm{C}$ value of -68.1 indicates the degradation of ancient $\mathrm{C}$ as the main $\mathrm{C}$ source in the initial soils (Gülland et al., 2013b). In addition, the $\mathrm{C}$ content at 5-10 cm depth (400-500 $\mu \mathrm{g} \mathrm{Cg}^{-1}$ ) was similar to the $\mathrm{C}$ content in the top soil of the most recently deglaciated soils (700$1100 \mu \mathrm{g} \mathrm{Cg} \mathrm{g}^{-1}$, Bernasconi et al., 2011), indicating that organic material has been blended into the soil.

Esperschütz et al. (2011) used ${ }^{13} \mathrm{C}$ labelled litter to study the microbial food web in the initial soils. C flow through the food web was traced using phospholipid fatty acids and phospholipid ether lipids. In the initial soils, archaea, fungi and protozoa were enriched in ${ }^{13} \mathrm{C}$. The community pattern changed only slightly towards the developed soils, where actinomycetes were involved in litter degradation. After twelve weeks of incubation, the litter degradation in the initial soils was comparable to that in the developed soils, again highlighting the activity of heterotrophic microorganisms in the initial soil.

Gülland et al. (2013a) studied C losses from the initial soils at the Damma Glacier that were ice-free for $10 \mathrm{yr}$. Within the study period of three summer months,
$33 \mathrm{~g} \mathrm{C} \mathrm{m}^{-2}$ were released via respiration and $2 \mathrm{~g} \mathrm{C} \mathrm{m}^{-2}$ leached from the soil. Taking into consideration the total $\mathrm{C}$ stocks of $90 \mathrm{~g} \mathrm{C} \mathrm{m}^{-2}$ at the Damma Glacier, these data indicate a highly active microbial community degrading the soil organic matter. Similarly, Bardgett and Walker (2004) described a heterotrophic stage of C decomposition at Ödenwinkelkees Glacier, Austria.

In contrast to small changes in clay mineralogy, pronounced shifts of soil organic matter quality with increasing age of the clay fractions were found at the Damma Glacier (Dümig et al., 2012). Clay-bound organic matter from the 15-yr-old soils was mainly inherited organic $\mathrm{C}$ rich in aromatic compounds and rich in compounds carrying carboxyl groups. With increasing age of the clay fractions (75 and $120 \mathrm{yr}$ ), the formation of organo-mineral associations started with the sorption of proteinaceous compounds and microbial-derived carbohydrates on mineral surfaces. In the acidic soils, ferrihydrite (determined as oxalate-soluble iron) was the main provider of mineral surfaces and thus important for the stabilization of organic matter. We assume that sorption is not the only protective mechanism as poorly crystalline Fe phases also interact with organic matter by coprecipitation or micro-aggregation. These results show that organo-mineral associations already evolve in early stages of soil development, whereby mineral weathering and organic matter accumulation proceed in different timescales (Dümig et al., 2012).

Different pools of $\mathrm{N}$ are present in the initial soils. As summarized in Table 1, the content of total $\mathrm{N}$ ranges around $70 \mu \mathrm{g} \mathrm{N} \mathrm{g}^{-1}$, while the contents of microbial $\mathrm{N}\left(6 \mu \mathrm{g} \mathrm{N} \mathrm{g}^{-1}\right)$, nitrate $\left(0.1 \mu \mathrm{g} \mathrm{g} \mathrm{g}^{-1}\right)$, and ammonium $\left(0.03 \mu \mathrm{g} \mathrm{N} \mathrm{g}^{-1}\right)$ are considerably lower. As for $\mathrm{C}$, different $\mathrm{N}$ sources contribute $\mathrm{N}$ to the glacier forefield: (i) $\mathrm{N}$ fixation by microorganisms and (ii) $\mathrm{N}$ deposition. As shown in Fig. 2, $\mathrm{N}$ fixation is very low in the initial soils at the Damma Glacier. Duc et al. (2009) detected $\mathrm{N}$ fixation activity in the range of $2 \mathrm{pmol} \mathrm{C}_{2} \mathrm{H}_{4} \mathrm{~g}^{-1} \mathrm{~h}^{-1}$, using the acetylene reduction assay. Another study found $\mathrm{N}$ fixation rates below $0.2 \mathrm{pmol} \mathrm{N} \mathrm{h}^{-1} \mathrm{~g}^{-1}$ in the initial soils, using the stable isotope incorporation method (Brankatschk et al., 2011). The lowest $\mathrm{N}$ fixation activity was accompanied by the lowest abundance of the $\mathrm{N}$ fixation marker gene nifH $(2 \times$ $10^{6}$ copies $^{-1}$ ) at initial sites, confirming the presence of few microorganisms capable of the $\mathrm{N}$ fixation process. In contrast to the $\mathrm{N}$ fixation, the deposition of $\mathrm{N}$ is several orders of magnitude higher (Brankatschk et al., 2011). Estimations for wet deposition of nitrate and ammonium ranged between 7 and $11 \mathrm{~kg} \mathrm{Nha}^{-1} \mathrm{a}^{-1}$. The total $\mathrm{N}$ deposition is estimated to be 10 to $15 \mathrm{~kg} \mathrm{Nha}^{-1} \mathrm{a}^{-1}$. This indicates the importance of the $\mathrm{N}$ deposition as the primary $\mathrm{N}$ source in the forefield, and is supported by stable isotope measurements. The $\mathrm{N}$ in the initial soils exhibits $\delta^{15} \mathrm{~N}$ values of -4 to -2 , which appear to be typical for initial soils in cold climates and can be explained by the negative $\delta^{15} \mathrm{~N}$ of atmospheric N (Smittenberg et al., 2012). The quantification of organic detritus 
Table 1. Plant and soil parameters from initial (6-13 yr), transient (60-80 yr) and developed (110-150 yr) sites and a reference site ( $>2000 \mathrm{yr})$ outside the glacier forefield. All nutrient values and the microbial biomass $\mathrm{C}$ are given in $\mu \mathrm{g} \mathrm{g}^{-1}$. Data were summarized from Bernasconi et al. (2011), Brankatschk et al. (2011), Göransson et al. (2011), Hämmerli et al. (2007) and Noll and Wellinger (2008).

\begin{tabular}{|c|c|c|c|c|}
\hline & \multicolumn{4}{|c|}{ Approximate soil age } \\
\hline & $6-13 \mathrm{yr}$ & $60-80 \mathrm{yr}$ & $110-150 \mathrm{yr}$ & $2000 \mathrm{yr}$ \\
\hline Plant coverage & $<10 \%$ & $>70 \%$ & $100 \%$ & $100 \%$ \\
\hline Dominant vegetation & $\begin{array}{l}\text { Agrostis gigantea, } \\
\text { Rumex scutatus, } \\
\text { Cerastium uniflorum, } \\
\text { Oxyria digyna }\end{array}$ & $\begin{array}{l}\text { Agrostis gigantea, } \\
\text { Salix spp., } \\
\text { Deschampsia cespitosa, } \\
\text { Athyrium alpestre }\end{array}$ & $\begin{array}{l}\text { Rhododendron } \\
\text { ferrugieum, Salix spp., } \\
\text { Agrostis gigantea, } \\
\text { Festuca rubra }\end{array}$ & Agrostis gigantea \\
\hline $\mathrm{pH}_{C a C l 2}$ & 5.5 & 4.7 & 4.6 & 3.6 \\
\hline $\begin{array}{l}\text { Maximum water holding } \\
\text { capacity }[\%]\end{array}$ & 3.5 & 2.4 & 4.8 & 6.7 \\
\hline Microbial biomass $\mathrm{C}$ & 58 & 122 & 241 & 902 \\
\hline Microbial biomass $\mathrm{N}$ & 6 & 19 & 29 & 115 \\
\hline Total C & 700 & 4700 & 12000 & 39600 \\
\hline Total N & 70 & 250 & 730 & 2670 \\
\hline Dissolved organic C & 7 & 18 & 42 & 78 \\
\hline Dissolved organic $\mathrm{N}$ & 0.3 & 0.9 & 3 & 12 \\
\hline $\mathrm{NO}_{3}^{-}$ & 0.1 & 0.2 & 1.3 & 0.8 \\
\hline $\mathrm{NH}_{4}^{+}$ & 0.03 & 0.2 & 7 & 13 \\
\hline $\mathrm{NaHO}_{3}$ extractable $\mathrm{P}$ & 6.7 & 9.7 & 7.8 & n.d. \\
\hline $\mathrm{S}$ & 0.25 & 1.25 & 870.7 & 1300 \\
\hline
\end{tabular}

on snow revealed that approximately $0.6 \mathrm{~kg} \mathrm{Nha}^{-1} \mathrm{a}^{-1}$ is deposited as particulate organic matter. Decomposition and mineralization of this organic matter was suggested to be the dominant $\mathrm{N}$ transformation process in the initial soils at the Damma Glacier (Brankatschk et al., 2011), which is declared as initial phase in Fig. 2. Also, the marker genes for the breakdown of organic matter, chitinase (chiA) and protease (aprA) were detected in the initial soils. The abundance of chiA gene was $7 \times 10^{5}$ copies $^{-1}$, and the aprA gene was quantified with $6 \times 10^{6}$ copies $^{-1}$. Activities of other $\mathrm{N}$ turnover processes such as nitrification and denitrification were low $\left(<2 \mathrm{nmol} \mathrm{N} \mathrm{g}{ }^{-1} \mathrm{~h}^{-1}\right)$ in the initial soils (Brankatschk et al., 2011).

The abundance of the marker gene for nitrification amoA of ammonia oxidizing bacteria (AOB) was two orders of magnitude higher $\left(2 \times 10^{6}\right.$ copies $\left.^{-1}\right)$ than for ammonia oxidizing archaea (AOA) (Brankatschk et al., 2011), which stands in contrast to many others studies (Leininger et al., 2006; Schauss et al., 2009). It might be that the conditions in the initial soils are more ideal for AOB. On the one hand ammonium is supplied from atmospheric deposition and mineralization of organic matter, while competition about ammonium with plants is low. On the other hand the low $\mathrm{pH}$ of the soil is more favourable for AOB than AOA (Gubry-Rangin et al., 2011). However, at the same time potential nitrification measurements were low (Brankatschk et al., 2011). This can be explained by two scenarios: (i) The AOB community at the initial sites of the glacier forefield is inactive per se or (ii) the AOB community is adapted to the harsh condi- tions at the initial sites and is not able to adapt to laboratory conditions, thus turnover rates during potential nitrification measurements are low.

From the analyzed marker genes for denitrification, the nirK gene was the most abundant one with $1.5 \times$ $10^{8}$ copies $\mathrm{g}^{-1}$. Since potential denitrification activity was low, the high nirK gene abundance might indicate the presence of facultative anaerobic bacteria in the initial soils, and would support the hypothesis of the dominance of mineralizing microorganisms that are adapted to temporarily waterlogged conditions, e.g. during heavy rains or snow melt. The established $\mathrm{C}$ and $\mathrm{N}$ cycle in the glacier forefield leads to the accumulation of protein-rich organic matter in the very early stages of soil development, which includes a stronger accumulation of carbohydrate-rich material in the course of time, both most probably of microbial origin (Dümig et al., 2012).

$\mathrm{P}$, next to $\mathrm{N}$, is frequently found to be the limiting nutrient in terrestrial ecosystems. Therefore, the release of $\mathrm{P}$ from the minerals in the bedrock was at the centre of studies at the Damma Glacier. The granite bedrock contains approximately $400-600 \mu \mathrm{g} \mathrm{Pg}^{-1}$ soil that is bound to apatite. However, recent field studies in alpine habitats suggest that apatite has a limited impact on the microbial structures and function (Ragot et al., 2013). The amount of organic $\mathrm{P}$ and deposited $\mathrm{P}$ in the initial soil is low, accounting for 50-60 $\mathrm{\mu g} \mathrm{P} \mathrm{g}^{-1}$ (Tamburini et al., 2010; Göransson et al., 2011) and $0.1-1.2 \mathrm{~kg} \mathrm{Pha}^{-1} \mathrm{a}^{-1}$ (Binder et al., 2009). An even smaller proportion of the $\mathrm{P}$, however, is freely available as phosphate $\left(0.8 \mu \mathrm{g} \mathrm{P}^{-1}\right)$ as determined by resin bag 


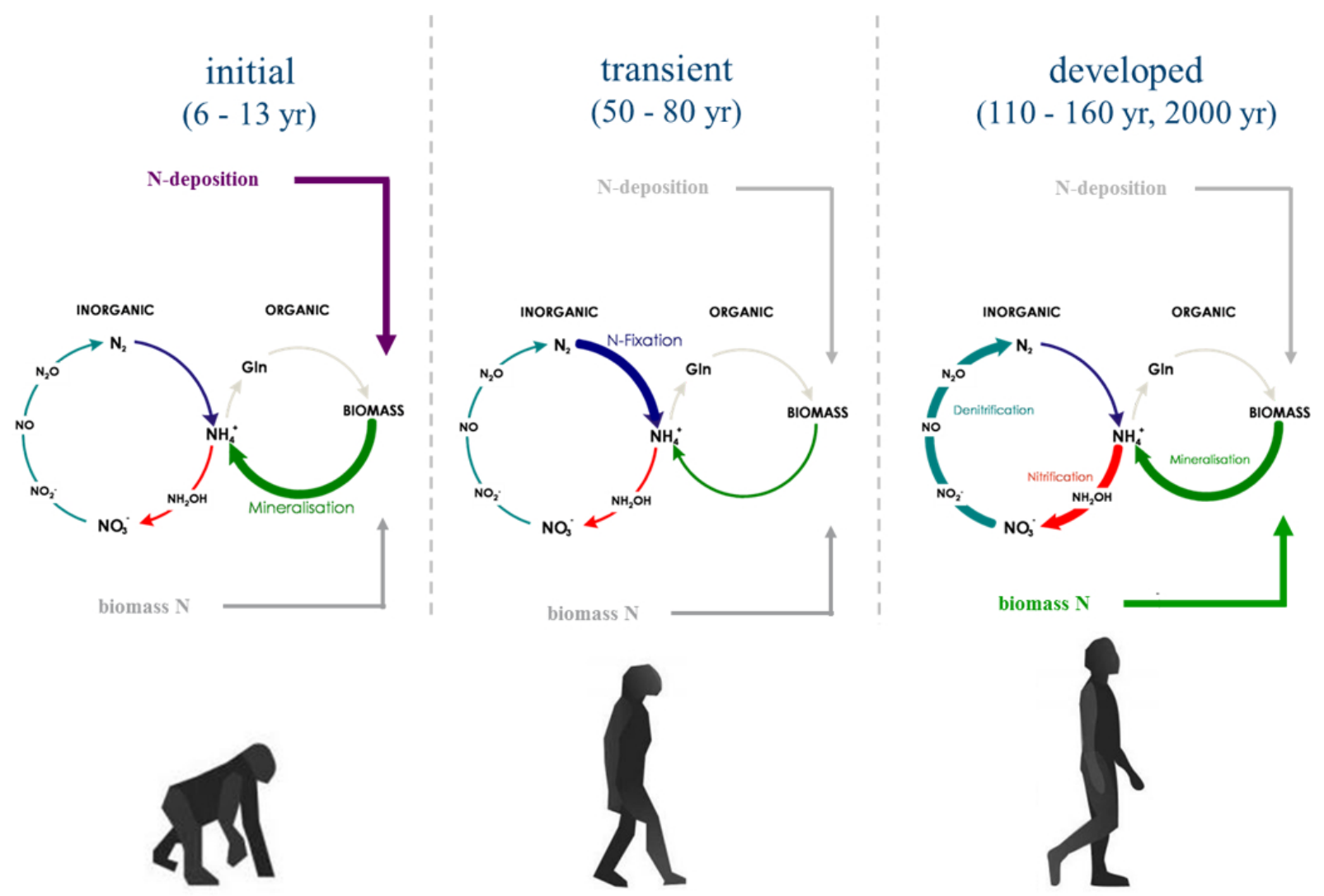

Fig. 2. The development of the microbial $\mathrm{N}$ cycle during soil formation. To exclude the strong influence of the increasing biomass along the glacier forefield, underlying data were related to ng DNA to be able to compare results from different development stages. Figure modified after Ollivier et al. (2011).

experiments (Bernasconi et al., 2011). Nevertheless, the heterotrophic microorganisms as well as plants from the initial soils were not $\mathrm{P}$ limited (Göransson et al., 2011). However, the isotopic analysis of the plants $\mathrm{P}$ source showed that the minerals are the major $\mathrm{P}$ source and deposition plays a minor role (Tamburini et al., 2010). This might underline the microbial importance of mineral dissolution during the initial soil formation process. The dissolution of $\mathrm{P}$ and other nutrients from the minerals might be accelerated by microorganisms releasing organic acids or chelators. This was investigated in mineral dissolution experiments using bacterial isolates from the Damma forefield (Lapanje et al., 2012). Selected isolates were screened for high mineral dissolution potential; however, the abiotic controls using citric and hydrochloric acid released elements at significantly higher rates than the bacterial isolates did (Lapanje et al., 2012). Future studies need to investigate the $\mathrm{P}$ release from mineral bedrock in the initial soils, as the mechanisms have not been studied in detail, but are crucial for the development of the ecosystem.

Significant amounts of $\mathrm{S}$ are required to maintain the high ecosystem productivity that was measured at the forefield of the Damma Glacier (Smittenberg et al., 2012). In the bedrock a total of approximately $5 \mu \mathrm{g} \mathrm{g} \mathrm{g}^{-1}$ is present (Lazzaro et al.,
2009; Bernasconi et al., 2011), and concentrations of available sulfate in the initial soils range from $0.25 \mu \mathrm{g} \mathrm{S} \mathrm{g}^{-1}$ (Table 1). However, in the developed soils the $S$ content is in the range of $300 \mu \mathrm{g} \mathrm{S} \mathrm{g}^{-1}$ (Bernasconi et al., 2011). Borin et al. (2010) pointed out the importance of S-oxidising bacteria as first colonizers in microbial communities at the Midtre Lovénbreen Glacier, Svalbard. If similar processes prevailed at the Damma Glacier, this would indicate that sulfate is quickly released from the minerals of the initial soil and might therefore be available for plants early on. A study on desulfonating bacteria, i.e. bacteria that release sulfate from organic matter, found very high diversity at the Damma forefield (Schmalenberger and Noll, 2010). Therefore, it was hypothesized $\mathrm{S}$ might be a limiting nutrient. As indicated above, the $\mathrm{S}$ content in the soil is low in the initial soils and the $\mathrm{S}$ stocks in the developed soil cannot be explained by mineral dissolution only. Therefore, the $\mathrm{S}$ deposition might significantly contribute to the $\mathrm{S}$ budget of the forefield. The deposition of $\mathrm{S}$ is estimated to be 200 to $350 \mathrm{mg} \mathrm{SO}_{\mathrm{X}} \mathrm{m}^{-2} \mathrm{a}^{-1}$ (Nyiri et al., 2009); however, a detailed analysis on S sources in the Damma forefield, e.g. deposition measurements or isotope analysis, is lacking. 


\section{Biofilms and soil crusts as hotspots of nutrient turnover}

Initial sites of glacier forefields are characterized by less vegetation and low nutrient contents. In 2005 the vegetation cover at the Damma Glacier was below $20 \%$ at a distance of $80 \mathrm{~m}$ to the glacier front, which corresponds to approximately $13 \mathrm{yr}$ of soil development (Hämmerli et al., 2007). Therefore, it is obvious that the initial processes of soil formation and input of nutrients rely on the activity of microorganisms. In principal two main functions can be assigned to the microbes: (i) the biological weathering of the bedrock material and (ii) the formation of interfaces for nutrient turnover at vegetation free sites.

Regarding biological weathering, Frey et al. (2010) demonstrated that isolates from the granitic sand in front of the Damma Glacier were able to effectively dissolve the siliceous bedrock material. The main underlying mechanism for the dissolution is the formation of biofilms on the mineral surface. Organisms being organized in such biofilms exude organic acids like oxalic acid, which on the one hand lead to a ligand-promoted dissolution and on the other hand to a proton-promoted dissolution because of the decreasing $\mathrm{pH}$. The released elements are then captured in the polysaccharide matrix of the biofilm and display therefore a nutrient hotspot in the bare substrate. In addition to that mechanism, Büdel et al. (2004) attributed an important role in biological weathering to cryptoendolithic Cyanobacteria, which enhance weathering by alkalization of the substrate during photosynthesis.

It was ascertained by several researchers that the trophic base at initial sites of glacier forefields is established by first colonizers like Cyanobacteria, green algae, lichens, mosses and fungi, which often conglomerate and form biological soil crusts (BSCs) (Belnap et al., 2001a). The formation of BSCs is strongly linked to the environmental conditions present, as well as to the parental material. As shown in Fig. 3, BSC development at the Damma Glacier is very heterogeneous and strongly depends on the right equilibrium of water availability and water holding capacity of the substrate. These BSCs fulfil different important roles in the ecosystem development. Most BSCs forming organisms are able to perform photosynthesis and/or $\mathrm{N}$ fixation, and thus enhance $\mathrm{C}$ and $\mathrm{N}$ content of the soils. In this regard, researchers stated that under optimal conditions the performance per unit ground surface of BSC is similar or even higher than that of vascular plants (Yoshitake et al., 2009; Pointing and Belnap, 2012). Moreover, Dickson et al. (2000) showed that the $\mathrm{N}_{2}$-fixation activity of BSCs was already measurable at $3{ }^{\circ} \mathrm{C}$. Thus, the "vegetation period" of BSCs starts much earlier than that of vascular plants and nutrient input is prolonged, which is especially advantageous at glacier forefields. Nutrient acquisition is further supported by the excretion of exopolysaccharides by several Cyanobacteria, which are often coated with clay particles. The negatively charged clay particles are associated with positively charged nutrients in turn, and prevent those from leaching (Belnap et al., 2001a). At the Damma Glacier the highest numbers of Cyanobacteria have been found at the initial sites, including Lecanoromycetes, to which a lot of lichen-forming species belong (Zumsteg et al., 2012). A second study, which focused on nifH-carrying microbes, revealed a cyanobacterial community comparable to mature BSC from the Colorado plateau (Duc et al., 2009; Yeager et al., 2004). The dominant species were Nostoc sp. and Scytonema sp. Both are able to produce pigments, which enable them to withstand high solar radiation. This property is a big advantage at glacier forefields because radiation strongly increases during summertime and day temperatures can reach up to $40^{\circ} \mathrm{C}$ at the soil surface (Miniaci et al., 2007), while the thermal radiation at night hampers the storage of heat energy from the day (Landolt, 1992). Thus, poikilohydric organisms, which form BSCs, have a big advantage as they are able to withstand drought and high solar radiation, and as soon as they are rewetted the activity strongly increases. Although crust forming bacteria have been detected at initial sites of the Damma Glacier, the formation of bacterial dominated crusts at the sampling site was not observed (Duc et al., 2009). This might be mainly attributed to the exposed position of some parts of the initial sites to the glacier tongue, which leads to regular disturbances of the surface by the glacial stream. However, as soon as sites are more protected against erosion, either due to moraines or their location on hydrologic islands, moss and lichen dominated crusts develop (Bernasconi et al., 2011, Fig. 3), which is in accordance with observations in the Negev Desert (Israel) (Zaady et al., 2000). Interestingly, these types of crusts are often associated with vegetation patches (Duc et al., 2009). It is very likely that crusts were there before plants established, as they are known to pave the way for vascular plants, because on the one hand BSCs improve soil fertility and on the other hand they create advantageous micro-environments for plant germination and growth (Belnap et al., 2001b).

Regarding the soil fertility, data from different BSCs indicate that crusts have $200 \%$ higher $\mathrm{N}$ content than uncrusted soils from the same site (Harper and Belnap, 2001; Rogers and Burns, 1994; Pointing and Belnap, 2012). However due to increased microbial activities and leaching of $\mathrm{N}$ to deeper soil layers (Johnson et al., 2007), nitrogen is still one of the limiting factors in BSCs. Brankatschk et al. (2011) demonstrated that deposited $\mathrm{N}$ and $\mathrm{C}$ are important drivers for the ecosystem development at initial sites; the ability of Cyanobacteria to trap nutrient-rich deposits via their exopolysaccharide sheath even facilitates that effect (Reynolds et al., 2001). Thus, also decomposing microbes are stimulated in BSCs, which in turn supply plants in the vicinity with a lot of different micronutrients and trace elements. As arctic and alpine plant species often have a shallow root system due to the thin soil layers, they can easily acquire the nutrient sources below BSCs (Billings, 1987). 

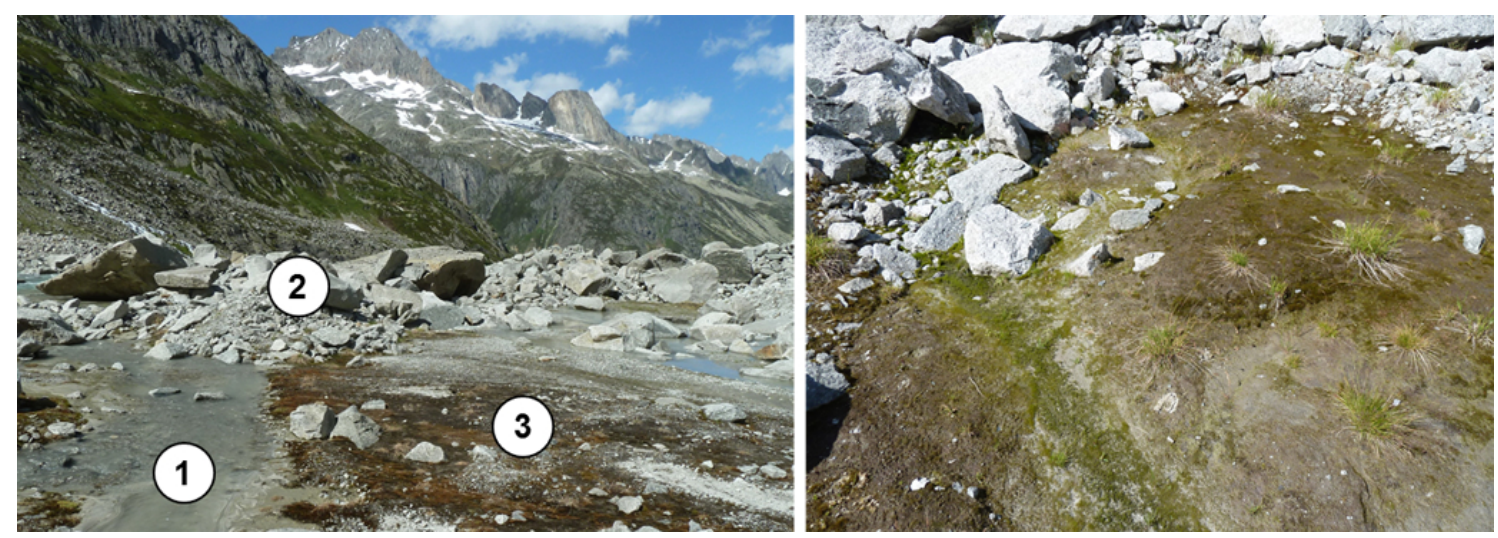

Fig. 3. BSCs at initial sites of the forefield of the Damma Glacier. The left picture shows that BSCs do not develop when water has destructive properties (1) or when the water holding capacity of the substrate is too low (2). However, under optimal hydrological conditions and in areas protected against erosion, BSCs develop (3). The right picture illustrates the frequently observed proximity of BSC and plants. Photos: J. Zeyer.

BSCs did not only enhance the soil nutrient status, but also improved the physical conditions for plant establishment. The rough surface structure and the dark colour of BSCs create beneficial conditions for seedling settlement and germination, because they are sheltered against external disturbances and the temperature is higher compared to bare surrounding soils (Escudero et al., 2007; Breen and Lévesque, 2008; Gold, 1998). Moreover, the stress for pioneering plants is generally reduced - on the one hand because of the already mentioned nutrient conditions, and on the other hand because of the volumetric water content being higher in BSCs (Breen and Lévesque, 2008). Altogether, BSCs are able to buffer the diurnal changes in climatic conditions at glacier forefields and therefore reduce stress conditions, which otherwise might hamper the plant development.

Although a lot of effort is still necessary to directly characterize the BSCs at the forefield of the Damma Glacier, a lot of data indirectly underline their pivotal role in the ecosystem development. In summary, one can assign several functions to BSCs and biofilms at the forefield of the Damma Glacier. At the beginning of soil formation, microorganisms organized in biofilms contribute to the weathering of bedrock material and the dissolution of trace elements. Afterwards, their main function is the input of nutrients to the bare soil and the stabilization of the surface. That result then is the basis for the settlement and growth of plants, which will finally completely replace BSCs.

\section{Role of plants}

During the succession at the forefield of the Damma Glacier, the coverage of plants increased with soil age from $20 \%$ to $70 \%$ (Hämmerli et al., 2007). Plants play an important role in the stabilization of the slope (Körner, 2004) and the soil development, as their root exudates and decaying litter mate- rial are the main sources of organic matter at initial sites of the glacier forefield (Duc et al., 2009). Although the microbial biomass is much lower at initial sites, the decomposition of plant material is as fast as it is at developed sites over a time period of twelve weeks (Esperschütz et al., 2011). Interestingly, initial sites of the Damma Glacier and other alpine glaciers are dominated by forbs and grasses like Leucanthemopsis alpina, Agrostis gigantea or Cerastium uniflorum, whereas legumes like Lotus alpinus or Trifolium pallescens appear later in succession although their symbiosis with rhizobia might be an advantage at $\mathrm{N}$-poor initial sites (Miniaci et al., 2007; Göransson et al., 2011; Tscherko et al., 2003). There are two reasons explaining the absence of legumes from the initial sites. First, many legumes like Lotus alpinus form heavier seeds than L. alpina or C. uniflorum (Pluess et al., 2005; Tackenberg and Stöcklin, 2008), and thus dispersal via wind is more difficult. Second, the establishment and maintenance of a rhizobia-legume symbiosis is a very energy consuming process (Merbach et al., 1999), and therefore energy consumption might be too high under these harsh conditions. However, in contrast to alpine glacier forefields, at Glacier Bay (Alaska) symbiotic N fixers like Dryas drummondii and a single species of alder are already dominant at initial sites. That difference might be mainly attributed to climatic conditions. While at Glacier Bay a mild and maritime climate with small annual and diurnal temperature changes predominates, the forefield of the Damma Glacier is characterized by strong temperature variations and irregularly distributed rainfall during the year, both being unfavourable for effective plant establishment (Bernasconi, 2008; Landolt, 1992; Miniaci et al., 2007).

Several studies at the Damma Glacier showed that pioneering plants display a nutrient hotspot at initial sites (Töwe et al., 2010; Duc et al., 2009; Miniaci et al., 2007). Thus, much higher abundances and activities of microbes were detected in the rhizosphere of pioneering plants. In initial soils this 
effect is even expanded up to a distance of $20 \mathrm{~cm}$ (Miniaci et al., 2007). The phenomenon of enhanced microbial activity and abundance in the rhizosphere of plants is known as the "rhizosphere effect" (Butler et al., 2003; Hartmann et al., 2008). Regarding the Damma Glacier the rhizosphere effect is generally more pronounced at initial sites compared to developed ones (Töwe et al., 2010; Edwards et al., 2006). This observation seems to be a general effect independent of plant species, bedrock material or climatic conditions. For example, Deiglmayr et al. (2006) detected only a significant difference in the nitrate reductase activity at the initial sites of the Rotmoosferner Glacier. This activity was 23 times higher in the rhizosphere of Poa alpina compared to the bulk soil. The enhancement of microbial activity and abundance in the rhizosphere is mainly attributed to uncontrolled leakage or controlled exudation of organic substances like malate, citrate or oxalate. Thus, it is unquestionable that plants display a nutrient hotspot in terms of $\mathrm{C}$, as they provide up to $40 \%$ of the photosynthetically fixed $\mathrm{CO}_{2}$ to the microbes (Paterson and Sim, 2000). In return, microbes supply the plant with $\mathrm{N}$, phosphate or other nutrients and additionally protect them against herbivores or parasites.

Interestingly, the highest abundances of $\mathrm{N}$ fixers in the bulk soil in connection with highest $\mathrm{N}$ fixation activity in the rhizosphere of $L$. alpina have been detected at intermediate development stages (transient phase in Fig. 2), where the $\mathrm{N}$ content is still low but plant coverage has already strongly increased, which hints at a competition between microbes and plants for N (Brankatschk et al., 2011; Duc et al., 2009). This theory is further corroborated by results from Töwe et al. (2010), where the abundance of nifH carrying microbes was highest in the rhizosphere of L. alpina planted in a $10 \mathrm{yr}$ soil, which was connected with the lowest $\mathrm{C} / \mathrm{N}$ ratios of plant biomass. However, during incubation the $\mathrm{N}$ content of L. alpina grown in the $10 \mathrm{yr}$ soil strongly increased while plant and root biomass stayed stable, as shown in Fig. 4, which fits with the assumption that microbes are able to win the competition over a short timescale because of their higher volume-surface ratio, higher growth rate and substrate affinity (Hodge et al., 2000). On the contrary, plants are more effective over a long time period because of their longer lifespan and the ability to retain the assimilated $\mathrm{N}$ (Hodge et al., 2000; Nordin et al., 2004). In addition to the enrichment of $\mathrm{N}$ fixing microbes, heterotrophic mineralizers like chiA-containing microbes are also enhanced (Tscherko et al., 2004; Töwe et al., 2010). The degradation of chitin and proteins has the advantage that low-weight organic compounds consisting of $\mathrm{C}$ and $\mathrm{N}$ are released. The ability of plants to assimilate amino acids, amino sugar or small peptides seems to be ubiquitously distributed among different ecosystems and plays a particular role in cold and wet habitats (Näsholm et al., 2009; Lipson and Monson, 1998; Schimel and Bennett, 2004). In parallel, functional groups leading to $\mathrm{N}$ losses like nitrifying or denitrifying microbes were reduced in the rhizosphere, which is in line with the assumption that plants are able to actively influence their rhizosphere community (Singh et al., 2004) by changing their exudation pattern or by actively excreting substances like tannins, polyphenolic substances or monoterpenes (Briones et al., 2003; Kowalchuk and Stephen, 2001; Ward et al., 1997; Cocking, 2003). In this regard, Edwards et al. (2006) detected changes in the exudation pattern of L. alpina along the forefield of the Damma Glacier mainly attributed to a strong reduction of oxalic and citric acid concentrations. In general, it seems that indeed microbial activity and abundance is much higher in the rhizosphere of pioneering plants compared to the bulk soil, but the community composition is strongly driven by the bulk soil community, whereas at developed sites the plant determines the microbial community in the rhizosphere (Duc et al., 2009; Miniaci et al., 2007). The strength of that phenomenon has been proven for functional groups like nifHcontaining microbes as well as for overall bacterial diversity from different sites and by different methods like PLFA analysis (Tscherko et al., 2004; Bardgett and Walker, 2004), clone libraries (Duc et al., 2009), pyrosequencing (Knelman et al., 2012) and fingerprinting methods (Deiglmayr et al., 2006; Miniaci et al., 2007).

With ongoing succession a shift from a competition for $\mathrm{N}$ to a competition for phosphate takes place (Vitousek and Farrington, 1997). While phosphate is not limited at the beginning of succession as it is released during weathering of the siliceous bedrock material (Ragot et al., 2013), the concentration of bioavailable phosphate steadily decreases along the glacier chronosequence, thus favouring ecto- and ericoid mycorrhizal associations (Bernasconi et al., 2011). A similar trend was found at Glacier Bay (Alaska), where a symbiosis with legumes has been found already in very young soils, but the first mycorrhiza-forming plants appear later in succession (Chapin et al., 1994).

Anyhow, as soon as vegetation cover is nearly closed, the ecosystem development speeds up so that ecosystem properties are similar to mature ecosystems. This includes increasing amounts of organic $\mathrm{C}$ and $\mathrm{N}$, the formation of soil horizons, increasing microbial biomass and enzyme activities even in the bulk soil (Dümig et al., 2011; Brankatschk et al., 2011; Duc et al., 2009; Sigler and Zeyer, 2002). Once a stable plant community has developed, a positive feedback loop establishes. The plants still provide fixed $\mathrm{CO}_{2}$ via rhizodeposition to the microbial community. Additionally, the high input of dead plant material provides a broad nutrient source for decomposing microbes. Thus, in contrast to sparsely vegetated sites, sufficient amounts of $\mathrm{N}$ are released during mineralization of high molecular compounds, which is then again available for plants. Moreover, climatic conditions like water content, temperature and radiation are more stable below a closed plant cover, leading to a reduction of environmental stressors, which are strongly pronounced in initially poorly vegetated sites.

Finally, one can summarize that plants play a crucial role in ecosystem development, but their function changes during 


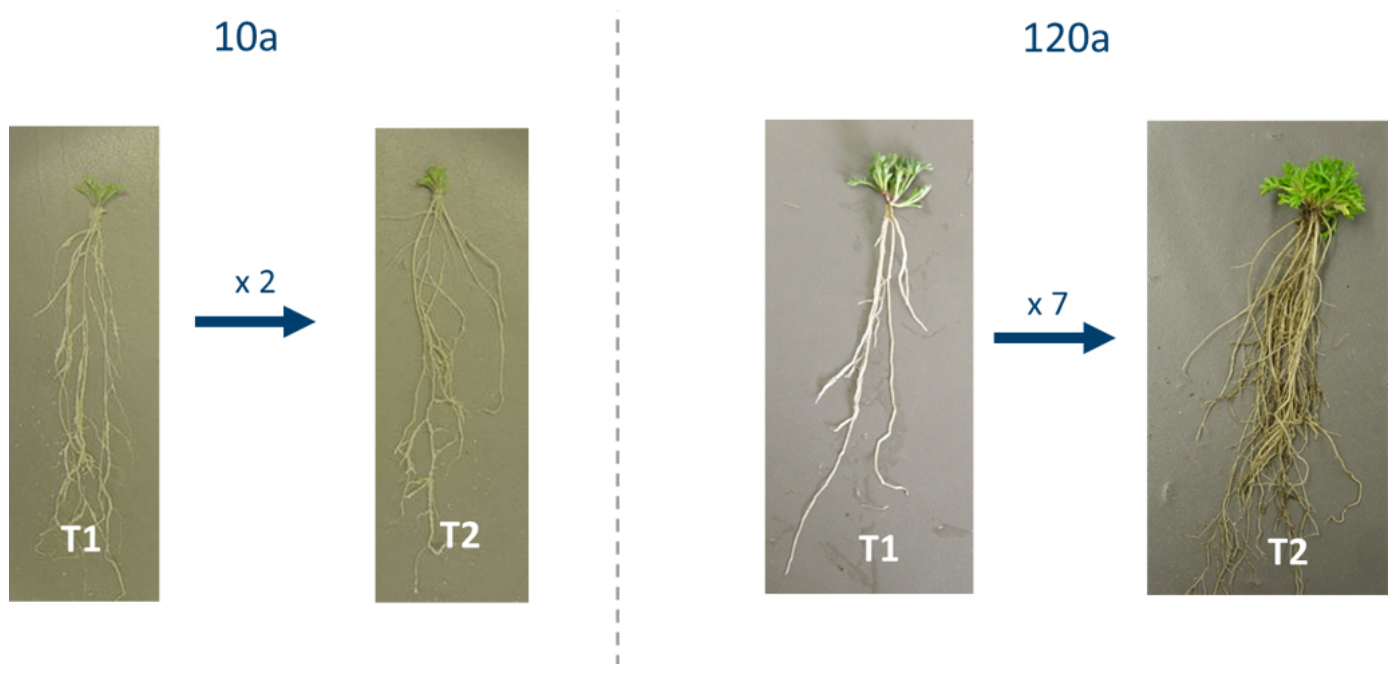

Fig. 4. Development of root biomass of L. alpina grown in soils obtained from the Damma chronosequence that have been ice free for 10 and $120 \mathrm{yr}$, respectively, at two different points in time of plant development ( 2 weeks and 8 weeks of growth) in a green house experiment.

succession. At initial stages their pivotal role in stabilizing the slope and providing $\mathrm{C}$ is unquestionable, but similarly they compete for scarce nutrients like $\mathrm{N}$ with the microbes. The succession of plant establishment strongly depends on the external conditions. Thus, at alpine glacier forefields higher plants establish later compared to glacier forefields with maritime climate, where shrubs and small trees can already be found at very young sites (Bardgett and Walker, 2004).

\section{Lessons learned from the Damma Glacier chronosequence for ecosystem development}

1. Initial ecosystems can emerge as a consequence of different events. These systems include, for example, forefields of retreating glaciers, chronosequences related to volcanic eruptions, post-mining areas and permanent mechanical disturbance at coastal and inland dunes. For initial ecosystems the following phases of development can be assumed: (i) the system properties are driven by physical structures and hydrological processes, (ii) the importance of chemical processes increases and (iii) biological communities drive ecosystem properties and development (Schaaf et al., 2011). However, the individual time of development strongly depends on the external conditions like bedrock material, altitude, meteorological properties, initial C, or the degree of mechanical disturbance.

2. The knowledge gained from the Damma Glacier showed that not only the presence of biota but also the interaction of organisms is the key for ecosystem development. Regarding the microbial N cycle, development takes place in three phases. Initially, allochthonous
$\mathrm{N}$ sources are mineralized. As soon as plant biomass and with that competition on the rare $\mathrm{N}$ sources increase, $\mathrm{N}$ fixation becomes more important. Finally, when the surface is completely covered with plants the $\mathrm{N}$ cycling community becomes more complex, and $\mathrm{N}$ is mostly derived from biomass. It is obvious that biological "hotspots" like BSCs can accelerate the development of initial ecosystems. It has been shown that the development of the nitrogen cycle in the Damma chronosequence and that in the BSCs of inland dunes are characterized by similar phases.

3. The presented review indicates that the development of initial ecosystems cannot be accelerated by "simple" management strategies like reforestation, irrigation or fertilization. Biotic-abiotic interactions and appropriate soil structures must be established first to pave the way for higher plants. For example, the growth of higher plants in an initial phase can be limited because applied fertilizers will leach into the groundwater and essential mycorrhizal communities are lacking. Therefore, it will be a future challenge to find and establish adequate strategies to accelerate the development of initial ecosystems.

Acknowledgements. This study is part of the Transregional Collaborative Research Centre 38 (SFB/TRR 38), which is financially supported by the Deutsche Forschungsgemeinschaft (DFG, Bonn) and the Brandenburg Ministry of Science, Research and Culture (MWFK, Potsdam). Moreover, we thank Anita Zumsteg for providing Fig. 1. Finally, we thank the anonymous reviewers for their helpful comments to improve the manuscript.

Edited by: W. Gerwin 


\section{References}

Aneja, M., Sharma, S., Schloter, M., and Munch, J. C.: Microbial degradation of beech litter - Influence of soil type and litter quality on the structure and function of microbial populations involved in the turnover process, Microb. Ecol., 52, 127-135, 2006.

Bardgett, R. D. and Walker, L. R.: Impact of coloniser plant species on the development of decomposer microbial communities following deglaciation, Soil Biol. Biochem., 36, 555-559, 2004.

Belnap, J., Büdel, B., and Lange, O. L.: Biological Soil Crusts: Characteristics and Distribution, in: Biological Soil Crusts: Structure, Function, and Management, edited by: Belnap, J. and Lange, O. L., Springer, Berlin, Heidelberg, 2001a.

Belnap, J., Prasse, R., and Harper, K. T.: Influence of biological soil crusts on soil environments and vascular plants, in: Biological Soil Crusts: Structure, Function, and Management, edited by: Belnap, J. and Lange, O. L., Springer, Berlin, Heidelberg, 281300, 2001b.

Bernasconi, S. M.: Weathering, soil formation and initial ecosystem evolution on a glacier forefield: a case study from the Damma Glacier, Switzerland, Mineral Mag, 72, 19-22, 2008.

Bernasconi, S. M., Bauder, A., Bourdon, B., Brunner, I., Bünemann, E., Chris, I., Derungs, N., Edwards, P., Farinotti, D., Frey, B., Frossard, E., Furrer, G., Gierga, M., Göransson, H., Gülland, K., Hagedorn, F., Hajdas, I., Hindshaw, R., Ivy-Ochs, S., Jansa, J., Jonas, T., Kiczka, M., Kretzschmar, R., Lemarchand, E., Luster, J., Magnusson, J., Mitchell, E. A. D., Venterink, H. O., Plötze, M., Reynolds, B., Smittenberg, R. H., Stähli, M., Tamburini, F., Tipper, E. T., Wacker, L., Welc, M., Wiederhold, J. G., Zeyer, J., Zimmermann, S., and Zumsteg, A.: Chemical And Biological Gradients Along The Damma Glacier Soil Chronosequence, Switzerland, Vadzone, 10, 867-883, 2011.

Billings, W. D.: Constraints to Plant Growth, Reproduction, and Establishment in Arctic Environments, Arctic Alpine Res., 19, 357-365, 1987.

Binder, C. R., de Baan, L., and Wittmer, D.: Phosphorflüsse der Schweiz, Bundesamt für Umwelt (BAFU), 28, 1-163, 2009.

Blumenthaler, M., Ambach, W., and Ellinger, R.: Increase in solar UV radiation with altitude, J. Photochem. Photobiol., 39, 130134, 1997.

Borin, S., Ventura, S., Tambone, F., Mapelli, F., Schubotz, F., Brusetti, L., Scaglia, B., Acqui, L., Solheim, B., Turicchia, S., Marasco, R., Hinrichs, U., Baldi, F., Adani, F., and Daffonchio, D.: Rock weathering creates oases of life in a High Arctic desert, Environ. Microbiol., 12, 293-303, 2010.

Brankatschk, R., Töwe, S., Kleineidam, K., Schloter, M., and Zeyer, J.: Abundances and potential activities of nitrogen cycling microbial communities along a chronosequence of a glacier forefield, ISME J., 5, 1025-1037, 2011.

Bratteler, M., Lexer, C., and Widmer, A.: Genetic architecture of traits associated with serpentine adaptation of Silene vulgaris, J Evol. Biol., 19, 1149-1156, 2006.

Breen, K. and Lévesque, E.: The Influence of Biological Soil Crusts on Soil Characteristics along a High Arctic Glacier Foreland, Nunavut, Canada, Arct. Antarct. Alp. Res., 40, 287-297, 2008.

Briones, A. M., Okabe, S., Umemiya, Y., Ramsing, N.-B., Reichardt, W., and Okuyama, H.: Ammonia-oxidizing bacteria on root biofilms and their possible contribution to $\mathrm{N}$ use efficiency of different rice cultivars, Plant Soil, 250, 335-348, 2003.
Büdel, B., Weber, B., Kühl, M., Pfanz, H., Sültemeyer, D., and Wessels, D.: Reshaping of sandstone surfaces by cryptoendolithic cyanobacteria: bioalkalization causes chemical weathering in arid landscapes, Geobiology, 2, 261-268, 2004.

Butler, J. L., Williams, M. A., Bottomley, P. J., and Myrold, D. D.: Microbial community dynamics associated with rhizosphere carbon flow, Appl. Environ. Microbiol., 69, 6793-6800, 2003.

Chapin, F. S., Walker, L. R., Fastie, C. L., and Sharman, L. C.: Mechanisms of primary succession following deglaciation at Glacier Bay, Alaska, Ecol. Monogr., 64, 149-175, doi:10.2307/2937039, 1994

Cocking, E. C.: Endophytic colonization of plant roots by nitrogenfixing bacteria, Plant Soil, 252, 169-175, 2003.

Deiglmayr, K., Philippot, L., Tscherko, D., and Kandeler, E.: Microbial succession of nitrate-reducing bacteria in the rhizosphere of Poa alpina across a glacier foreland in the Central Alps, Environ. Microbiol., 8, 1600-1612, 2006.

Dickson, L. G.: Constraints to nitrogen fixation by cryptogamic crusts in a polar desert ecosystem, Devon Island, NWT, Canada, Arct. Antarct. Alp. Res., 32, 40-45, 2000.

Dijkstra, P., Ishizu, A., Doucett, R., Hart, S. C., Schwartz, E., Menyailo, O. V., and Hungate, B. A.: C-13 and N-15 natural abundance of the soil microbial biomass, Soil Biol. Biochem. 38, 3257-3266, 2006.

Doran, J.: Soil health and global sustainability: translating science into practice, Agricult. Ecosyst. Environ., 24, 119-127, 2002.

Duc, L., Noll, M., Meier, B., Bürgmann, H., and Zeyer, J.: High diversity of diazotrophs in the forefield of a receding alpine glacier, Microb. Ecol., 57, 179-190, 2009.

Dümig, A., Smittenberg, R., and Kögel-Knabner, I.: Concurrent evolution of organic and mineral components during initial soil development after retreat of the Damma glacier, Switzerland, Geoderma, 163, 83-94, 2011.

Dümig, A., Häusler, W., Steffens, M., and Kögel-Knabner, I.: Clay fractions from a soil chronosequence after glacier retreat reveal the initial evolution of organo-mineral associations, Geochim. Cosmochim. Ac., 85, 1-18, 2012.

Edwards, I. P., Burgmann, H., Miniaci, C., and Zeyer, J.: Variation in microbial community composition and culturability in the rhizosphere of Leucanthemopsis alpina (L.) heywood and adjacent bare soil along an alpine chronosequence, Microb. Ecol., 52, 679-692, 2006.

Egli, M., Wernli, M., Burga, C., Kneisel, C., Mavris, C., Valboa, G., Mirabella, A., Ploetze, M., and Haeberli, W.: Fast but spatially scattered smectite-formation in the proglacial area Morteratsch: An evaluation using GIS, Geoderma, 164, 11-21, 2011.

Escudero, A., Martínez, I., de la Cruz, A., Otálora, M. A. G., and Maestre, F. T.: Soil lichens have species-specific effects on the seedling emergence of three gypsophile plant species, J. Arid Environ., 70, 18-28, 2007.

Esperschütz, J., Pérez-de-Mora, A., Schreiner, K., Welzl, G., Buegger, F., Zeyer, J., Hagedorn, F., Munch, J. C., and Schloter, M.: Microbial food web dynamics along a soil chronosequence of a glacier forefield, Biogeosciences, 8, 3283-3294, doi:10.5194/bg8-3283-2011, 2011.

Fahnestock, J. T., Jones, M. H., Brooks, P. D., Walker, D. A., and Welker, J. M.: Winter and early spring $\mathrm{CO}_{2}$ flux from tundra communities of northern Alaska, J. Geophys. Res., 102, 925929, 1998. 
Frey, B., Rieder, S. R., Brunner, I., Plotze, M., Koetzsch, S., Lapanje, A., Brandl, H., and Furrer, G.: Weathering-associated bacteria from the Damma glacier forefield: physiological capabilities and impact on granite dissolution, Appl. Environ. Microbiol., 76, 4788-4796, 2010.

Frey-Klett, P., Garbaye, J., and Tarkka, M.: The mycorrhiza helper bacteria revisited, New Phytol., 176, 22-36, 2007.

Gold, W. G.: The influence of cryptogamic crusts on the thermal environment and temperature relations of plants in a high Arctic polar desert, Devon Island, NWT, Canada, Arctic Alpine Res., 30, 108-120, 1998.

Göransson, H., Olde Venterink, H., and Bååth, E.: Soil bacterial growth and nutrient limitation along a chronosequence from a glacier forefield, Soil Biol. Biochem., 43, 1333-1340, 2011.

Gubry-Rangin, C., Hai, B., Quince, C., Engel, M., Thomson, B. C., James, P., Schloter, M., Griffiths, R. I., Prosser, J. I., and Nicol, G. W.: Niche specialization of terrestrial archaeal ammonia oxidizers, P. Natl. Acad. Sci., 108, 21206-21211, 2011.

Gülland, K., Esperschütz, J., Bornhauser, D., Bernasconi, S. M., Kretzschmar, R., and Hagedorn, F.: Mineralisation and leaching of $\mathrm{C}$ from 13C labelled plant litter along an initial soil chronosequence of a glacier forefield, Soil Biol. Biochem., 57, 237-247, 2013a.

Gülland, K., Hagedorn, F., Smittenberg, R. H., Göransson, H., Bernasconi, S. M., Hajdas, I., and Kretzschmar, R.: Evolution of carbon fluxes during initial soil formation along the forefield of Damma glacier, Switzerland, Biogeochemistry, 113, 545-561, $2013 b$.

Hämmerli, A., Waldhuber, S., Miniaci, C., Zeyer, J., and Bunge, M.: Local expansion and selection of soil bacteria in a glacier forefield, Eur. J. Soil Sci., 58, 1437-1445, 2007.

Harper, K. T. and Belnap, J.: The influence of biological soil crusts on mineral uptake by associated vascular plants, J. Arid Environ., 47, 347-357, 2001.

Harris, C., Arenson, L. U., Christiansen, H. H., Etzelmüller, B., Frauenfelder, R., Gruber, S., Haeberli, W., Hauck, C., Hölzle, M., Humlum, O., Isaksen, K., Kääb, A., Kern-Lütschg, M. A., Lehning, M., Matsuoka, N., Murton, J. B., Nötzli, J., Phillips, M., Ross, N., Seppälä, M., Springman, S. M., and Vonder Mühll, D.: Permafrost and climate in Europe: Monitoring and modelling thermal, geomorphological and geotechnical responses, EarthSci. Rev., 92, 117-171, 2009.

Harrison, R. B. and Strahm, B.: Soil Formation, Encyclopedia of Ecology 3291-3295, 2008

Hartmann, A., Rothballer, M., and Schmid, M.: Lorenz Hiltner, a pioneer in rhizosphere microbial ecology and soil bacteriology research, Plant Soil, 312, 7-14, 2008.

Hodge, A., Robinson, D., and Fitter, A.: Are microorganisms more effective than plants at competing for nitrogen?, Trends Plant Sci., 5, 304-308, 2000.

Hodkinson I. D., Coulson S. J., and Webb, N. R.: Community assembly along proglacial chronosequences in the High Arctic: vegetation and soil development in north-west Svalbard, J Ecol., 91, 651-663, 2003.

Joerin, U., Stocker, T., and Schlüchter, Ch.: Multicentury glacier fluctuations in the Swiss Alps during the Holocene, The Holocene, 16, 697-704, 2006.

Johnson, S. L., Neuer, S., and Garcia-Pichel, F.: Export of nitrogenous compounds due to incomplete cycling within biological soil crusts of arid lands, Environ. Microbiol., 9, 680-689, 2007.

Kaštovská, K., Stibal, M., Šabacká, M., Černá, B., Šantrůčková, H., and Elster, J.: Microbial community structure and ecology of subglacial sediments in two polythermal Svalbard glaciers characterized by epifluorescence microscopy and PLFA, Polar Biol., 30, 277-287, 2007.

Knelman, J. E., Legg, T. M., O'Neill, S. P., Washenberger, C. L., González, A., Cleveland, C. C., and Nemergut, D. R.: Bacterial community structure and function change in association with colonizer plants during early primary succession in a glacier forefield, Soil Biol. Biochem., 46, 172-180, 2012.

Kobierska, F., Jonas,T., Magnusson, J., Zappa, M., Bavay, M., Bosshard, T., Paul, F., and Bernasconi, S.: Climate change effects on snow melt and discharge of a partly glacierized watershed in Central Switzerland (SoilTrec Critical Zone Observatory), App. Geochem., 26, S60-S62, 2011.

Körner, C.: Alpine plant life, Springer, Heidelberg, 1999.

Körner, C.: Mountain biodiversity, its causes and function, Ambio, 13, 11-17, 2004.

Kowalchuk, G. A. and Stephen, J. R.: Ammonia-oxidizing bacteria: A model for molecular microbial ecology, Annu. Rev. Microbiol., 55, 485-529, 2001.

Landolt, E.: Unsere Alpenflora, Gustav Fischer Verlag, Stuttgart, 1992.

Lapanje, A., Wimmersberger, C., Furrer, G., Brunner, I., and Frey, B.: Pattern of elemental release during the granite dissolution can be changed by aerobic heterotrophic bacterial strains isolated from Damma Glacier (central Alps) deglaciated granite sand, Microb. Ecol., 63, 865-882, 2012.

Lazzaro, A., Abegg, C., and Zeyer, J.: Bacterial community structure of glacier forefields on siliceous and calcareous bedrock, Europ. J. Soil Sc., 15, 291-301, 2009.

Leininger, S., Urich, T., Schloter, M., Schwark, L., Qi, J., Nicol, G. W., Prosser, J. I., Schuster, S. C., and Schleper, C.: Archaea predominate among ammonia-oxidizing prokaryotes in soils, Nature, 442, 806-809, 2006.

Lipson, D. A. and Monson, R. K.: Plant-microbe competition for soil amino acids in the alpine tundra: effects of freeze-thaw and dry-rewet events, Oecologia, 113, 406-414, 1998.

Lombard, N., Prestat, E., van Elsas, J. D., and Simonet, P.: Soilspecific limitations for access and analysis of soil microbial communities by metagenomics, FEMS Microbiol. Ecol., 78, 31-49, 2011.

Mavris, C., Egli, M., Ploetze, M., Blum, J. D., Mirabella, A., Giaccai, D., and Haeberli, W.: Initial stages of weathering and soil formation in the Morteratsch proglacial area (Upper Engadine, Switzerland), Geoderma, 155, 359-371, 2010.

Mavris, C., Ploetze, M., Mirabella, A., Giaccai, D., Valboa, G., and Egli, M.: Clay mineral evolution along a soil chronosequence in an Alpine proglacial area, Geoderma, 165, 106-117, 2011.

Merbach, W., Mirus, E., Knof, G., Remus, R., Ruppel, S., Russow, R., Gransee, A., and Schulze, J.: Release of carbon and nitrogen compounds by plant roots and their possible ecological importance, J. Plant Nutr. Soil Sci., 162, 373-383, 1999.

Miniaci, C., Bunge, M., Duc, L., Edwards, I., Burgmann, H., and Zeyer, J.: Effects of pioneering plants on microbial structures and functions in a glacier forefield, Biol. Fert. Soils, 44, 289-297, 2007. 
Monier, J. M., Demanèche, S., Delmont, T. O., Mathieu, A., Vogel, T. M., and Simonet, P.: Metagenomic exploration of antibiotic resistance in soil, Curr. Opin. Microbiol., 14, 229-235, 2011.

Näsholm, T., Kielland, K., and Ganeteg, U.: Uptake of organic nitrogen by plants, New Phytol., 182, 31-48, 2009.

Nordin, A., Schmidt, I. K., and Shaver, G. R.: Nitrogen uptake by arctic soil microbes and plants in relation to soil nitrogen supply, Ecology, 85, 955-962, 2004.

Noll, M. and Wellinger, M.: Changes of the soil ecosystem along a receding glacier: Testing the correlation between environmental factors and bacterial community structure, Soil Biol. Biochem., 40, 2611-2619, 2008.

Nyiri, A., Gauss, M., and Klein, H.: Transboundary data by main pollutants (S, N, O3) and PM, Country reports 2010 MSC-W Data Note 1/2010, ISSN 1890-0003, 2009.

Ollivier, J., Töwe, S., Bannert, A., Hai, B., Kastl, E. M., Meyer, A., $\mathrm{Su}, \mathrm{M} . X .$, Kleineidam, K., and Schloter, M.: Nitrogen turnover in soil and global change, FEMS Microbiol. Ecol., 78, 3-16, 2011.

Paterson, E. and Sim, A.: Effect of nitrogen supply and defoliation on loss of organic compounds from roots of Festuca rubra, J. Exp. Bot., 51, 1449-1457, 2000.

Paul, E. A. and Clark, F.: Soil Microbiology and Biochemistry, 2nd Edition, Academic Press, New York, 1996.

Paul, F., Kääb, A., Maisch, M., Kellenberger, T., and Haeberli, W.: Rapid disintegration of Alpine glaciers observed with satellite data, Geophys. Res. Lett., 31, 1-4, 2004.

Paul, F., Kääb, A. and Haeberli, W.: Recent glacier changes in the Alps observed from satellite: Consequences for future monitoring strategies, Global Planet. Change, 56, 111-122, 2007.

Pluess, A., Schütz, W., and Stöcklin, J.: Seed weight increases with altitude in the Swiss Alps (2007) between related species but not among populations of individual species, Oecologia, 144, 55-61, 2005.

Pointing, S. B. and Belnap, J.: Microbial colonization and controls in dryland systems, Nat. Rev. Microbiol., 10, 551-562, 2012.

Ragot, S., Zeyer, J., Zehnder, L., Reusser, E., Brandl, H., and Lazzaro, A.: Bacterial community structures of an alpine apatite deposit, Geoderma, 202-203, 30-37, 2013.

Rajendhran, J. and Gunasekaran, P.: Strategies for accessing soil metagenome for desired applications, Biotechnol. Adv., 26, 576590, 2008

Reynolds, R., Belnap, J., Reheis, M., Lamothe, P., and Luiszer, F.: Aeolian dust in Colorado Plateau soils: Nutrient inputs and recent change in source, P. Natl. Acad. Sci., 98, 7123-7127, 2001.

Rogers, S. L. and Burns, R. G.: Changes in aggregate stability, nutrient status, indigenous microbial populations, and seedling emergence, following inoculation of soil, Biol. Fert. Soils, 18, 209215,1994

Sawstrom, C., Mumford, P., Marshall, W., Hodson, A., and Laybourn-Parry, J.: The microbial communities and primary productivity of cryoconite holes in an arctic glacier (Svalbard $79^{\circ} \mathrm{N}$ ), Polar Biol., 25, 591-596, 2002.

Schaaf, W., Bens, O., Fischer, A., Gerke, H. H., Gerwin, W., Grünewald, U., Holländer, H. M., Kögel-Knabner, I., Mutz, M., Schloter, M., Schulin, R., Veste, M., Winter, S., and Hüttl, R. F.: Patterns and processes of initial terrestrial-ecosystem development, J. Plant Nutr. Soil Sci., 174, 229-239, 2011.

Schauss, K., Focks, A., Leininger, S., Kotzerke, A., Heuer, H., Thiele-Bruhn, S., Sharma, S., Wilke, B.-M., Matthies, M.,
Smalla, K., Munch, J. C., Amelung, W., Kaupenjohann, M., Schloter, M., and Schleper, C.: Dynamics and functional relevance of ammonia-oxidizing archaea in two agricultural soils, Environ. Microbiol., 11, 446-456, 2009.

Schimel, J. P. and Bennett, J.: Nitrogen mineralization: Challenges of a changing paradigm, Ecol, 85, 591-602, 2004.

Schmalenberger, A. and Noll, M.: Shifts in desulfonating bacterial communities along a soil chronosequence in the forefield of a receding glacier, FEMS Microb. Ecol., 71, 208-217, 2010.

Sharma, S., Mehta, R., Gupta, R., and Schloter, M.: Improved protocol for the extraction of bacterial mRNA from soils, J. Microbiol. Methods, 91, 62-64, 2012.

Sigler, W. V. and Zeyer, J.: Microbial diversity and activity along the forefields of two receding glaciers, Microb. Ecol., 43, 397-407, 2002.

Simon, C. and Daniel, R.: Metagenomic analyses: past and future trends, Appl. Environ. Microbiol., 77, 1153-1161, 2011.

Singh, B. K., Millard, P., Whiteley, A. S., and Murrell, J. C.: Unravelling rhizosphere-microbial interactions: opportunities and limitations, Trends Microbiol., 12, 386-393, 2004.

Smittenberg, R., Gierga, M., Göransson, H., Christl, I., Farinotti, D., and Bernasconi, S.: Climate-sensitive ecosystem carbon dynamics along the soil chronosequence of the Damma glacier forefield, Switzerland, Glob. Change Biol., 18, 1941-1955, 2012.

Stibal, M., Tranter, M., Benning, L. G., and Řehák, J.: Microbial primary production on an Arctic glacier is insignificant in comparison with allochthonous organic carbon input, Environ. Microbiol., 10, 2172-2178, 2008.

Styriakova, I., Styriak, I., and Oberhänsli, H.: Rock weathering by indigenous heterotrophic bacteria of Bacillus spp. at different temperature: a laboratory experiment, Mineral. Petrol., 105, 135$144,2012$.

Tackenberg, O. and Stöcklin, J.: Wind dispersal of alpine plant species: A comparison with lowland species, J. Veg. Sci., 19 109-118, 2008.

Tamburini, F., Bernasconi, S. M., Angert, A., Weiner, T., and Frossard, E.: A method for the analysis of the $\mathrm{d}^{18} \mathrm{O}$ of inorganic phosphate in soils extracted with HCl, Eur. J. Soil Sc., 61, 10251032, 2010.

Torsvik, V. and Øvreås, L.: Microbial diversity and function in soil: from genes to ecosystems, Curr. Opin. Microbiol., 5, 240-245, 2002.

Totsche, K. U., Rennert, T., Gerzabek, M. H., Kögel-Knabner, I., Smalla, K., Spiteller, M., and Vogel, H.-J. : Biogeochemical interfaces in soil: The interdisciplinary challenge for soil science, J. Plant Nutr. Soil. Sci., 173, 88-99, 2010.

Töwe, S., Albert, A., Kleineidam, K., Brankatschk, R., Dümig, A., Welzl, G., Munch, J., Zeyer, J., and Schloter, M.: Abundance of microbes involved in nitrogen transformation in the rhizosphere of Leucanthemopsis alpina (L.) Heywood grown in soils from different sites of the Damma glacier forefield, Microb. Ecol., 60, 762-770, 2010.

Tscherko, D., Rustemeier, J., Richter, A., Wanek, W., and Kandeler, E.: Functional diversity of the soil microflora in primary succession across two glacier forelands in the Central Alps, Eur. J. Soil. Sci., 54, 685-696, 2003.

Tscherko, D., Hammesfahr, U., Marx, M. C., and Kandeler, E.: Shifts in rhizosphere microbial communities and enzyme activity of Poa alpina across an alpine chronosequence, Soil Biol. 
Biochem., 36, 1685-1698, 2004.

van Elsas, J. D., Costa, R., Jansson, J., Sjöling, S., Bailey, M., Nalin, R., Vogel, T. M., and van Overbeek. L.: The metagenomics of disease-suppressive soils - experiences from the METACONTROL project, Trends Biotechnol., 26, 591-601, 2008.

Vitousek, P. M. and Farrington, H.: Nutrient limitation and soil development: Experimental test of a biogeochemical theory, Biogeochemistry, 37, 63-75, 1997.

Ward, B. B., Courtney, K. J., and Langenheim, J. H.: Inhibition of Nitrosomonas europaea by monoterpenes from coastal redwood (Sequoia sempervirens) in whole-cell studies, J. Chem. Ecol., 23, 2583-2598, 1997.

Yeager, C. M., Kornosky, J. L., Housman, D. C., Grote, E. E., Belnap, J., and Kuske, C. R.: Diazotrophic community structure and function in two successional stages of biological soil crusts from the Colorado Plateau and Chihuahuan Desert, Appl. Environ. Microbiol., 70, 973-983, 2004.
Yoshitake, S., Uchida, M., Koizumi, H., Kanda, H., and Nakatsubo, T.: Production of biological soil crusts in the early stage of primary succession on a High Arctic glacier foreland, New Phytol., 186, 451-460, 2009.

Zaady, E., Kuhn, U., Wilske, B., Sandoval-Soto, L., and Kesselmeier, J.: Patterns of $\mathrm{CO}_{2}$ exchange in biological soil crusts of successional age, Soil Biol. Biochem., 32, 959-966, 2000.

Zumsteg, A., Luster, J., Göransson, H., Smittenberg, R., Brunner, I., Bernasconi, S., Zeyer, J., and Frey, B.: Bacterial, Archaeal and Fungal Succession in the Forefield of a Receding Glacier, Microb. Ecol., 63, 552-564, 2012. 